\title{
Human NK cells: from surface receptors to the therapy of leukemias and solid tumors
}

\author{
Lorenzo Moretta $^{1 *}$, Gabriella Pietra ${ }^{2,3}$, Elisa Montaldo ${ }^{2}$, Paola Vacca ${ }^{2}$, Daniela Pende ${ }^{3}$, Michela Falco ${ }^{1}$, \\ Genny Del Zotto ${ }^{1}$, Franco Locatelli, ${ }^{4,5}$, Alessandro Moretta ${ }^{2}$ and Maria Cristina Mingari ${ }^{2,3}$ \\ 1 Istituto Giannina Gaslini, Genova, Italy \\ ${ }_{2}^{2}$ Department of Experimental Medicine and Center of Excellence for Biomedical Research, University of Genova, Genova, Italy \\ ${ }^{3}$ IRCCS AOU San Martino-IST, Genova, Italy \\ ${ }^{4}$ Department of Pediatric Hematology and Oncology, IRCCS Ospedale Pediatrico Bambino Gesù, Rome, Italy \\ ${ }^{5}$ Università di Pavia, Pavia, Italy
}

\section{Edited by:}

Kendall A. Smith, Weill Medical

College of Cornell University, USA

\section{Reviewed by:}

Roland Jacobs, Hannover Medical University, Germany

Bent Rolstad, University of Oslo,

Norway

Vincent Vieillard, Institut National de la

Santé et de la Recherche Scientifique,

France

${ }^{*}$ Correspondence:

Lorenzo Moretta, Istituto Giannina

Gaslini, Via G. Gaslini n.5, Genova

16147, Italy

e-mail: Iorenzomoretta@

ospedale-gaslini.ge.it
Natural Killer (NK) cells are major effector cells of the innate immunity. The discovery, over two decades ago, of major histocompatibility complex-class I-specific inhibitory NK receptors and subsequently of activating receptors, recognizing ligands expressed by tumor or virus-infected cells, paved the way to our understanding of the mechanisms of selective recognition and killing of tumor cells. Although NK cells can efficiently kill tumor cells of different histotypes in vitro, their activity may be limited in vivo by their inefficient trafficking to tumor lesions and by the inhibition of their function induced by tumor cells themselves and by the tumor microenvironment. On the other hand, the important role of NK cells has been clearly demonstrated in the therapy of high risk leukemias in the haploidentical hematopoietic stem cell (HSC) transplantation setting. NK cells derived from donor HSC kill leukemic cells residual after the conditioning regimen, thus preventing leukemia relapses. In addition, they also kill residual dendritic cells and T lymphocytes, thus preventing both $\mathrm{GvH}$ disease and graft rejection.

Keywords: NK cells, killer Ig-like receptors, alloreactive NK cells, activating NK receptors, hematopoietic stem cell transplantation, acute leukemias, tumor microenvironment

\section{INTRODUCTION}

Natural Killer (NK) cells play a central role in innate immunity as they mediate early defenses against viral infections and, more in general, against pathogens. However, NK cells are also involved in immune surveillance against tumors and prevent dissemination of metastatic tumors $(1,2)$. The NK effector function against tumors and virus-infected cells is mostly related to their cytolytic activity. In addition, by the secretion of various cytokines and chemokines, NK cells promote inflammatory responses and exert a regulatory control on downstream adaptive immune responses by influencing not only the strength, but also the quality of $\mathrm{T}$ cell responses. $\mathrm{T}$ helper-1 responses, favored by NK cells, further contribute to anti-tumor and anti-virus defenses. In turn, NK cell function is regulated by cytokines, including IL-15, IL-2, and IL-18 (3) as well as by cell-to-cell interactions involving different cell types primarily dendritic cells (DC) (3-5), macrophages (6), and mesenchymal stromal cells $(7,8)$. NK cells migrate to inflamed tissue and to secondary lymphoid organs where they can encounter tumor cells and participate to the first line of defense against pathogens. NK cells originate from hematopoietic stem cells (HSC) and undergo maturation primarily in the bone marrow (BM). However, evidence has been accumulated during the past several years that NK precursors at different stages of differentiation are present in tonsils (9), lymph nodes (10), decidua (11), and gut-associated lymphoid tissues (12). In addition, precursors capable of undergoing in vitro differentiation toward NK cells were isolated from human thymus over two decades ago (13).

\section{INHIBITORY AND ACTIVATING NK RECEPTORS: PAST AND PRESENT}

In spite of their functional relevance in defenses against viruses and tumors, NK cells remained mysterious and poorly considered for many years after their discovery (14-16) so that core questions regarding the molecular mechanisms involved in their ability to discriminate between normal and tumor or virus-infected cells remained unanswered. However, starting in early 90 s, we began to gain a fair idea on the mechanisms regulating NK cell activation and function. In late 80s, Ljunggren and Kärre had proposed the "missing self hypothesis" (17), based on the observation that NK cells could efficiently kill a murine lymphoma cell line that had lost major histocompatibility complex (MHC)-class I, while the parental MHC-class $\mathrm{I}^{+}$lymphoma cells were resistant to lysis. Thus, it appeared that NK cells could sense MHC-class I molecules, sparing MHC-class $\mathrm{I}^{+}$cells while killing MHC-class $\mathrm{I}^{-}$ cells. In addition, a clue that NK cells could sense even allelic differences on hematopoietic target cells was provided by the hybrid resistance phenomenon in which NK cells could reject parental BM graft in F1 hybrid mice (18). Another experiment suggesting that MHC-class I molecules could influence NK cell function was the detection of human NK cell proliferation in mixed lymphocyte culture against stimulating cells from unrelated donors (in the presence of IL-2). In addition, such cultured NK cells could lyse phytohemagglutinin (PHA) blasts isolated from the same stimulating donor (19). Taken together, these data were compatible with the expression, at the NK cell surface, of 
inhibitory receptors sensing MHC-class I molecules. The discovery of surface molecules expressed by human NK cell subsets that could inhibit the NK cell cytotoxicity upon monoclonal antibody (mAb)-mediated crosslinking $(20,21)$, was the first step toward the identification of human leukocytes antigen (HLA)-class Ispecific inhibitory receptors recognizing allelic forms of HLA-C (22). Remarkably, in parallel, Yokoyama et al. had identified Ly49 molecules as the murine receptors for MHC-class I (23). A number of novel receptors belonging to the same Ig-superfamily of the two HLA-C-specific prototypes (named p58.1 and p58.2) were identified and collectively called killer Ig-like receptors (KIRs). They also recognized allelic forms of HLA-B or -A allotypes (2427). In addition, activating KIRs were discovered (28) that were similar to the corresponding inhibitory KIRs in the extracellular Ig-domains, but substantially differed in the transmembrane and in the intracytoplasmic portions (29). Both inhibitory and activating KIRs have been shown to play an important role in the cure of high risk leukemias in the haploidentical HSC transplantation setting (see below). Genetic analysis revealed that KIR-encoding genes evolved and diversified rapidly in primates and humans (30). Likewise the HLA loci, KIR sequences were found to be highly polymorphic. KIR genes are organized as a family in the leukocyte receptor complex in chromosome 19 and are inherited as haplotypes. KIR haplotypes exhibit variability in the number and type of genes and in allelic polymorphism of the individual KIR genes, resulting in extensive genetic diversity. On the basis of their gene content, KIR haplotypes have been divided into group A (with a fixed gene pattern mainly including inhibitory KIR) and group B (more variable and including several activating KIR) (31). Other receptors with different HLA-I specificities, including CD94/NKG2A and LIR-1, were discovered and characterized (32, 33). Since inactivation of NK cell function represents a central failsafe mechanism to prevent killing of normal self HLA-class $\mathrm{I}^{+}$cells, the existence of activating receptors that are triggered upon interaction with normal cells had to be postulated. Experiments aimed at identifying these receptors were successful and three important activating NK receptors named NKp46 (34, 35), NKp44 (36, 37 ), and NKp30 (38) were discovered and molecularly characterized (39). These molecules, collectively termed natural cytotoxicity receptors (NCRs), were found to play a central role in tumor cell recognition and killing. Additional surface molecules functioning as activating receptors or co-receptors were subsequently identified. Some of these molecules, primarily NKG2D and DNAM-1, were also shown to play an important role in target cell recognition and lysis $(40,41)$. Remarkably, the known ligands of such receptors are over-expressed or expressed de novo upon cell stress, particularly when consequent to tumor transformation or viral infection $(40,42,43)$. The fact that NK cell activation may occur only upon interaction with abnormal target cells represents an important checkpoint to control unnecessary NK cell activation (44). In case of NK cell interaction with ligand-positive stressed cells, the latter are protected from lysis because of the engagement of HLA-I-specific inhibitory NK receptors by HLA-I molecules expressed normally, or even upregulated in these cells. On the contrary, virus-infected or tumor cells lack the expression of HLA-I molecules and upregulate the expression of NK activating receptor ligands becoming susceptible to NK cell lysis. The ligands of the main activating NK receptors include the human leukocyte antigen-B-associated transcript 3 (BAT-3) and B7H6 for NKp30 $(45,46)$, a novel isoform of the mixed-lineage leukemia-5 protein (MLL5) for NKp44 (47), PVR (CD155) and Nectin-2 (CD112) for DNAM-1 (42), and MICA/B and ULBPs for NKG2D (43). Direct identification of such ligands in tumor cells may allow predicting whether a given tumor may be susceptible to NK-mediated killing (see below for details).

\section{NK CELLS AND SOLID TUMORS}

Besides specific T lymphocytes, also NK cells are thought to play an important role in cancer immunosurveillance. NK cells are capable of recognizing and killing a wide variety of tumor cells. NK cells are potentially capable of eliminating tumors with reduced or absent MHC-class I expression that evade $\mathrm{CD} 8^{+} \mathrm{T}$ cell-mediated control. Therefore, they are playing a complementary role in antitumor activity. Recent studies also suggest that NK cells recognize and kill cancer stem cells (CSCs) $(48,49)$. Within the tumor mass, CSCs represent a small subpopulation of quiescent, self-renewing, chemo- and radio-resistant cells and hence they are responsible for tumor relapses after cytoreductive therapies.

In clinical studies, the degree of NK-mediated cytotoxic activity has been inversely correlated with cancer incidence in long survey subjects (50). In addition, several studies have provided evidence that, in a variety of different solid tumors, such as lung, gastric, colorectal, and head and neck cancers, the presence of high numbers of tumor-infiltrating NK cells correlates with improved prognosis of cancer patients (51-53). Despite the fact that NK cells represent a potential tool to eliminate tumor cells, NK cell-based immunotherapy has resulted in limited clinical benefit (54). In particular, this holds true in the case of solid tumors, suggesting that mechanisms of resistance at the level of the tumor microenvironment may be prevailing in many cases. This may reflect the limited capacity of adoptively transferred NK cells to traffic to tumor sites $(55,56)$.

Of note, factors regulating NK cell recruitment into neoplastic tissues are highly influenced by the tumor type, and by the chemokine profile of the tumor microenvironment. Several studies suggested that certain solid malignancies are infiltrated by variable numbers of NK cells. Those include, non-small cell lung cancers (NSCLC), gastrointestinal sarcoma (GIST), colorectal and renal cell carcinoma, and lung metastases (57-59). A recent study suggested that $\mathrm{CD}^{+} 6^{+} \mathrm{NK}$ cells could scarcely infiltrate melanomas, hepatocellular carcinomas, breast cancers, and renal cell carcinomas (60). Other studies reported that NK cells in solid tumors are often not located in direct contact with tumor cells but within the stroma $(55,61)$ and usually functionally anergic.

Thus, tumor cells may have developed various escape mechanisms to avoid NK-mediated killing. Hence, the tumor cells themselves or even tumor stromal cells may be actively involved in inhibition of NK cell function. Indeed, the tumor microenvironment may greatly influence NK-mediated defenses by a number of immunosuppressive strategies. Similar to $\mathrm{T}$ cells, tumor-infiltrating NK cells may be inhibited in their functional capability $(57,62-64)$. It has been shown that impaired NK cell function is often associated with down-modulation of activating 
NK receptors. The molecular mechanisms underlying this downregulation are only partially understood. In this context, ligandinduced receptor down-regulation may play a relevant role. This may be consequent to receptor blocking by ligand shed from tumor cells or to intercellular transfer (a phenomenon known as trogocytosis) $(65,66)$. In addition, chronic ligand-induced stimulation of NK cells may account for the down-regulation of activating receptors such as NKG2D (67). Surface molecules expressed by tumor cells could also inhibit NK cell function. For example, MUC16, a glycoprotein expressed on the surface of ovarian cancer cells inhibits synapse formation between tumor cells and NK cells (68). In addition, cytokines or soluble mediators such as TGF- $\beta$ and PGE2, synthesized either by tumor or by stromal cells downregulate the surface expression of NKp30, NKp44, and NKG2D and, consequently, NK cell cytotoxicity and cytokine production $(69,70)$. Furthermore, the enzyme indoleamine 2,3-dioxygenase (IDO) (over-expressed by some tumor cells including melanomas) may also contribute to the establishment of immune tolerance in the tumor microenvironment. In this context, a recent study by our group in melanomas reported that NK cell function may be suppressed by IDO-generated L-kynurenine (a tryptophan-derived toxic metabolite) (71). Finally, also the pro-inflammatory cytokine macrophage migration inhibitory factor (MIF) has been shown to inhibit the NKG2D expression in peripheral blood (PB) NK cells derived from ovarian cancer patients (72) (Figure 1A).

The hypoxic condition in cancer tissues may also contribute to tumor escape from NK cells. In a recent study, we observed that hypoxia can significantly impair both the surface expression and the function of major activating $\mathrm{NK}$ receptors involved in tumor recognition, including NKp46, NKp30, NKp44, and NKG2D. Accordingly, the NK-mediated cytotoxicity against tumor cells was sharply decreased under hypoxia conditions (Figure 1A). Interestingly, hypoxia did not affect CD16 (Fc $\gamma$ RIII) expression and function. Therefore, NK cells maintained the ability to efficiently kill mAb-coated target cells. These data imply that even at low oxygen tension, targeting of tumors with mAbs may be effective by NK cell-mediated antibody dependent cellular cytotoxicity (ADCC) (73) (Figure 1B).

The described mechanisms of inhibition help to better understand how tumors and their microenvironment can alter the ability of NK cells to elicit an effective anti-tumor response. In view of the immunosuppressive effect exerted by tumor cells at the tumor site, new strategies are required to prevent inhibition of potentially efficient effector mechanisms, for example by blocking the soluble mediators with immunosuppressive activity. Notably, these strategies may be applied to design novel protocols of NK cell-based adoptive immunotherapy to treat solid tumors.

\section{NK CELLS IN THE THERAPY OF HIGH RISK LEUKEMIAS}

Over the past 40 years, allogeneic hematopoietic BM or HSC transplantation from HLA-matched donors has been increasingly used to treat thousands of patients with malignant (primarily leukemias) or non-malignant disorders (e.g., severe combined immunodeficiencies) $(74,75)$. However, approximately one-third of patients in need of an allograft do not find a compatible donor, including matched-unrelated donors (MUD) and umbilical cord blood (UCB). However, the majority of patients, particularly

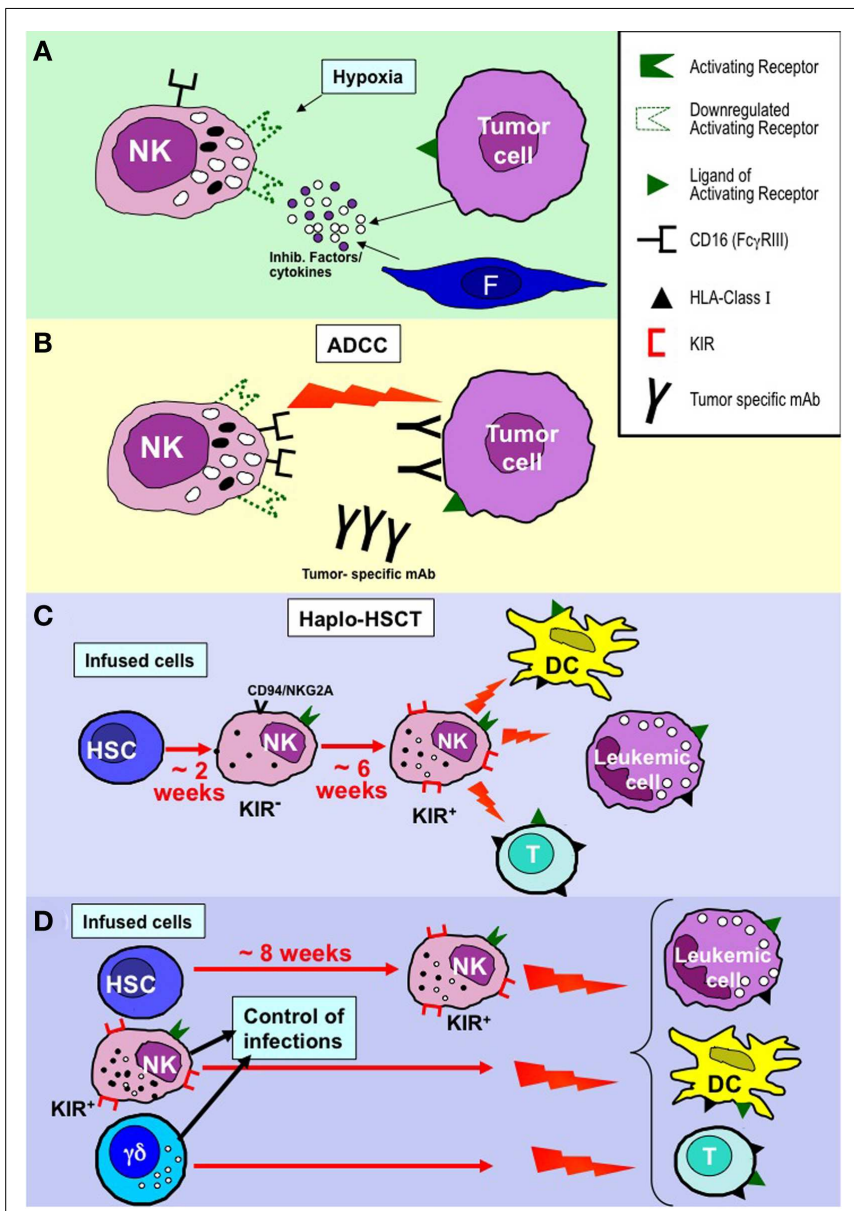

FIGURE 1 | NK cell-based approaches in the immunotherapy of tumors and leukemias. (A) NK cell function may be greatly hampered by inhibitory factors and/or cytokines produced by tumor cells or cells of the tumor microenvironment (e.g., fibroblasts, F) and by hypoxia that primarily induce down-regulation of activating NK receptors. (B) CD16-mediated antibody dependent cytotoxicity (ADCC) appears to be poorly susceptible to the inhibitory tumor microenvironment. This mechanism may contribute to the positive clinical outcome of patients treated with tumor-specific monoclonal antibodies (mAbs). (C) In the T-depleted haplo-HSCT, $\mathrm{KIR}^{+}$alloreactive NK cells derived from donor HSC (generated after 6-8 weeks) kill leukemia blasts (inducing GvL), DC (preventing GvHD), and T cells (preventing graft rejection) remaining after the conditioning regimen. (D) In haplo-HSCT, early leukemia relapses and severe viral infection may occur during the time interval (6-8 weeks) required for the generation of efficient alloreactive NK cells. The novel approach based on TCR $\alpha / \beta^{+}$- and B cell-depletion allows the infusion of donor-derived mature alloreactive NK cells and TCR $\gamma / \delta^{+}$cells together with HSC, thus allowing a better control of leukemia relapses, GvHD, graft rejection, and viral infection/reactivation.

children or young adults, have a family member identical for one HLA haplotype and mismatched for the other (the so-called haploidentical donor), who could serve as donor of HSC. This, haplo-HSC transplantation offered a promptly available treatment to any patient lacking a matched donor or suitable UCB units (7678). However, because of the incompatibility at three major HLA loci, it became clear that an extensive $\mathrm{T}$ cell depletion was strictly necessary to prevent fatal graft versus host $(\mathrm{GvH})$ reactions (79). 
T cell-depletion associated to high intensity immunosuppressive/myeloablative conditioning regimens and the use of very large numbers ("megadoses") of highly purified PB-derived CD34 ${ }^{+}$ cells resulted in: (a) the successful engraftment of HSC across the HLA barrier; (b) a very low incidence of grade II-IV acute GvH disease (GvHD), even in the absence of post-transplant prophylactic immune suppression (80-82). However, removal from the graft of mature T cells that, in HLA-matched transplants, are mainly responsible for protection from severe infections resulted in a state of immune deficiency for several months after transplantation. In order to overcome, at least in part, this major disadvantage, the adoptive infusion of $\mathrm{T}$ cell lines or clones specific for common lifethreatening pathogens, including cytomegalovirus, Epstein-Barr virus, adenovirus, and Aspergillus, has been applied successfully in pilot trials (83-85). Another possible consequence of the extensive $\mathrm{T}$ cell depletion was a higher rate of leukemia relapses. However, milestone studies in acute myeloid leukemia (AML) adult patients receiving a haplo-HSCT revealed that the graft versus leukemia (GvL) effect was mediated by NK cells generated from donor HSC. This effect was detectable almost exclusively in patients transplanted with donors who had NK cells alloreactive toward recipient cells. These studies clearly indicated that also cells of the innate immunity, such as NK cells, may guarantee a successful clinical outcome in this transplantation setting $(81,82)$.

The noticeable beneficial effect of alloreactive NK cells, first assessed in adult AML, was subsequently reported in children with high risk acute lymphoid leukemia (ALL) $(82,86,87)$. Indeed, the probability of leukemia relapse was very low and the survival rate was at least as good as that of patients receiving a HLA-matched sibling or unrelated donor. Notably, the NK-mediated GvL effect is separated by the occurrence of GvHD, thus clearly indicating that alloreactive NK cells kill leukemia blasts while sparing normal tissues, despite the KIR-HLA-I mismatch. In view of the favorable clinical outcome and the immediate availability of a family haploidentical donor, haplo-HSCT has been included as a valuable option for treating pediatric patients with life-threatening leukemias (88).

In haplo-HSCT, the first wave (occurring after 2-3 weeks) of $\mathrm{NK}$ cells derived from donor $\mathrm{CD} 34^{+}$HSC cells is composed of CD56 ${ }^{\text {bright }}$ cells expressing CD94/NKG2A as the only HLAI-specific receptor. These cells are relatively immature and display low levels of cytolytic activity. The appearance of $\mathrm{KIR}^{+} \mathrm{NK}$ cells (containing the alloreactive subset) requires four to six additional weeks. Therefore, it is conceivable that an efficient NK-mediated anti-leukemic effect occurs only after this time interval from transplantation (87, 89-91) (Figure 1C).

Given the central role of alloreactive NK cells in preventing leukemia relapses, information on the size of the alloreactive subset in potential donors appeared particularly relevant for optimal donor selection (92). In addition, this information was crucial to assess the generation of this subset in the recipient and its persistence over time. The basic criteria applied for donor selection have been the phenotypic identification of the alloreactive NK cell subset and the assessment of the NK cytotoxicity against leukemia cells $(87,93)$. Cytofluorimetric analysis, using appropriate combinations of monoclonal antibodies conjugated with different fluorochromes, allowed to identify the alloreactive subset. While only inhibitory KIRs were originally assessed, the more recent availability of mAbs, capable of discriminating between activating and inhibitory KIRs, allowed to extend the analysis to activating KIRs and to better define the size of this subset. This revealed to be particularly important for prevention of leukemia relapses, primarily in donors expressing the activating KIR2DS1, provided that patient's cells express the ligand of such activating receptor (i.e., HLA-C2 alleles) $(87,93,94)$. Other selection criteria have been added that are fundamental particularly in donorpatient pairs in whom no alloreactive NK cells can be found. One is based on KIR genotype analysis, since selection of donors with KIR B haplotypes was associated with significant improvement in disease free survival in adult AML patients. This suggests that activating KIRs, particularly those located in the centromeric portion, play a positive role in $\mathrm{GvL}(95,96)$. In addition, mothers were found to be better donors than fathers (97). By applying all these criteria to donor selection, the survival rate of patients receiving a haplo-HSCT is now over 70\% in children with high risk, otherwise fatal, ALL.

As specified above, in haplo-HSCT, the appearance of $\mathrm{KIR}^{+} \mathrm{NK}$ cells may require 6-8 weeks after donor $\mathrm{CD} 34^{+}$cell transplantation. Therefore, their anti-leukemia effect is relatively delayed. In case of rapidly proliferating leukemia blasts and/or of high tumor burden residual after the conditioning regimen, this delay may result in leukemic relapses as well as in impaired control of infections (74). In order to minimize this risk, donor-derived mature alloreactive NK cells, either resting or expanded in vitro, can be infused at transplantation or shortly after. A particularly promising approach based on the negative selection of $\mathrm{T}$ lymphocytes expressing the $\alpha \beta$ TCR associated with B cell depletion has recently been applied (98) (Figure 1D). This approach allows the accurate removal of $\alpha \beta$ T cells, responsible for the occurrence of GvHD. In addition, in this novel transplantation setting, it is possible not only to transfer to the recipient high numbers of $\mathrm{CD} 34^{+}$cells, but also mature NK cells and $\gamma \delta$ T cells. Thus, mature, alloreactive NK cells can promptly exert their anti-leukemia activity and prevent GvHD. A similar effect can be mediated by $\gamma \delta$ T cells in virtue of their ability to kill leukemia blasts (which express ligands recognized by NK cells and/or $\gamma \delta$ T cells). In addition, both cell types can control viral infections or reactivation that may represent lifethreatening complications in these patients (99). Additional donor selection criteria can be based also on the higher proportion of NK and $\gamma \delta$ T cells in their PB. Preliminary data are particularly encouraging even against pediatric AML that were not cured efficiently by the conventional haplo-HSCT approach upon infusion of CD34 ${ }^{+}$ cells (Locatelli et al. study in progress). An additional particularly promising approach resides in NK cell manipulation using anti-KIR mAbs (100). These mAbs, now studied in phase II clinical trials in patients with multiple myeloma or AML, can stably block KIRs and allow NK-mediated killing of autologous or HLAmatched tumor or leukemia cells, thus conferring alloreactivity to any $\mathrm{KIR}^{+} \mathrm{NK}$ cell.

In conclusion, the discovery of NK cell receptors and of the NK alloreactivity represented a true revolution in allo-HSCT and in the cure of otherwise fatal leukemias. 


\section{ACKNOWLEDGMENTS}

This work was supported by grants awarded by Associazione Italiana Ricerca sul Cancro (AIRC): IG 2010 project n. 10225 (Lorenzo Moretta), and "Special Program Molecular Clinical Oncology $5 \times 1000$ " project n. 9962 (Lorenzo Moretta, Alessandro Moretta, and Franco Locatelli), MFAG project n. 6384 (Gabriella Pietra); Ministero dell'Istruzione, Università e Ricerca (MIUR): MIUR-FIRB 2003 project RBLA039LSF-001 (Lorenzo Moretta); Ministero della Salute: RF2006-Ricerca OncologicaProject of Integrated Program 2006-08, agreements n. RO strategici 3/07 (Lorenzo Moretta) and RO strategici 8/07 (Maria Cristina Mingari and Gabriella Pietra); Ricerca Finalizzata: RF-IG-20081200689 (Maria Cristina Mingari), RF-2010-2316319 (Daniela Pende), RF-2010-2316606 (Franco Locatelli and Daniela Pende); MIUR-PRIN 2009 project 2009T4TC33_004 (Maria Cristina Mingari) and International Leibniz Research Cluster (ILRC) Network project "ImmunoMemory" funded by the Senatsausschuss Wettbewerb (SAW) 2012-15. Elisa Montaldo is recipient of a fellowship awarded by Fondazione Italiana per la Ricerca sul Cancro (FIRC).

\section{REFERENCES}

1. Trinchieri G. Biology of natural killer cells. Adv Immunol (1989) 47:187-376. doi:10.1016/S0065-2776(08)60664-1

2. Moretta L, Ciccone E, Mingari MC, Biassoni R, Moretta A. Human natural killer cells: origin, clonality, specificity, and receptors. Adv Immunol (1994) 55:341-80. doi:10.1016/S0065-2776(08)60513-1

3. Agaugue S, Marcenaro E, Ferranti B, Moretta L, Moretta A. Human natural killer cells exposed to IL-2, IL-12, IL-18, or IL-4 differently modulate priming of naive T cells by monocyte-derived dendritic cells. Blood (2008) 112(5):1776-83. doi:10.1182/blood-2008-02-135871

4. Ferlazzo G, Tsang ML, Moretta L, Melioli G, Steinman RM, Munz C. Human dendritic cells activate resting natural killer (NK) cells and are recognized via the NKp30 receptor by activated NK cells. J Exp Med (2002) 195(3):343-51. doi:10.1084/jem.20011149

5. Moretta A. Natural killer cells and dendritic cells: rendezvous in abused tissues. Nat Rev Immunol (2002) 2(12):957-64. doi:10.1038/nri956

6. Bellora F, Castriconi R, Dondero A, Reggiardo G, Moretta L, Mantovani A, et al. The interaction of human natural killer cells with either unpolarized or polarized macrophages results in different functional outcomes. Proc Natl Acad Sci U S A (2010) 107(50):21659-64. doi:10.1073/pnas.1007654108

7. Spaggiari GM, Capobianco A, Abdelrazik H, Becchetti F, Mingari MC, Moretta L. Mesenchymal stem cells inhibit natural killer-cell proliferation, cytotoxicity, and cytokine production: role of indoleamine 2,3-dioxygenase and prostaglandin E2. Blood (2008) 111(3):1327-33. doi:10.1182/blood-2007-02074997

8. Spaggiari GM, Capobianco A, Becchetti S, Mingari MC, Moretta L. Mesenchymal stem cell-natural killer cell interactions: evidence that activated NK cells are capable of killing MSCs, whereas MSCs can inhibit IL-2-induced NK-cell proliferation. Blood (2006) 107(4):1484-90. doi:10.1182/blood-200507-2775

9. Freud AG, Becknell B, Roychowdhury S, Mao HC, Ferketich AK, Nuovo GJ, et al. A human CD34(+) subset resides in lymph nodes and differentiates into CD56bright natural killer cells. Immunity (2005) 22(3):295-304. doi:10.1016/j.immuni.2005.01.013

10. Ferlazzo G, Thomas D, Lin SL, Goodman K, Morandi B, Muller WA, et al. The abundant NK cells in human secondary lymphoid tissues require activation to express killer cell Ig-like receptors and become cytolytic. J Immunol (2004) 172(3):1455-62.

11. Vacca P, Vitale C, Montaldo E, Conte R, Cantoni C, Fulcheri E, et al. CD34+ hematopoietic precursors are present in human decidua and differentiate into natural killer cells upon interaction with stromal cells. Proc Natl Acad Sci U S A (2011) 108(6):2402-7. doi:10.1073/pnas.1016257108
12. Chinen H, Matsuoka K, Sato T, Kamada N, Okamoto S, Hisamatsu T, et al. Lamina propria c-kit+ immune precursors reside in human adult intestine and differentiate into natural killer cells. Gastroenterology (2007) 133(2):559-73. doi:10.1053/j.gastro.2007.05.017

13. Mingari MC, Poggi A, Biassoni R, Bellomo R, Ciccone E, Pella N, et al. In vitro proliferation and cloning of CD3- CD16+ cells from human thymocyte precursors. J Exp Med (1991) 174(1):21-6. doi:10.1084/jem.174.1.21

14. Herberman RB, Nunn ME, Holden HT, Lavrin DH. Natural cytotoxic reactivity of mouse lymphoid cells against syngeneic and allogeneic tumors. II. Characterization of effector cells. Int J Cancer (1975) 16(2):230-9. doi:10.1002/ijc. 2910160205

15. Herberman RB, Nunn ME, Lavrin DH. Natural cytotoxic reactivity of mouse lymphoid cells against syngeneic acid allogeneic tumors. I. Distribution of reactivity and specificity. Int J Cancer (1975) 16(2):216-29. doi:10.1002/ijc. 2910160205

16. Kiessling R, Klein E, Wigzell H. "Natural" killer cells in the mouse. I. Cytotoxic cells with specificity for mouse Moloney leukemia cells. Specificity and distribution according to genotype. Eur J Immunol (1975) 5(2):112-7. doi:10.1002/eji.1830050208

17. Ljunggren HG, Karre K. In search of the 'missing self': MHC molecules and NK cell recognition. Immunol Today (1990) 11(7):237-44. doi:10.1016/01675699(90)90097-S

18. Rembecki RM, Bennett M, Kumar V, Potter TA. Expression of hemopoietic histocompatibility antigens on $\mathrm{H}$-2-loss variants of F1 hybrid lymphoma cells: evidence consistent with trans gene regulation. J Immunol (1987) 138(8): 2734-8.

19. Ciccone E, Viale O, Pende D, Malnati M, Biassoni R, Melioli G, et al. Specific lysis of allogeneic cells after activation of CD3- lymphocytes in mixed lymphocyte culture. J Exp Med (1988) 168(6):2403-8. doi:10.1084/jem.168.6. 2403

20. Moretta A, Bottino C, Pende D, Tripodi G, Tambussi G, Viale O, et al. Identification of four subsets of human CD3-CD16+ natural killer (NK) cells by the expression of clonally distributed functional surface molecules: correlation between subset assignment of NK clones and ability to mediate specific alloantigen recognition. J Exp Med (1990) 172(6):1589-98. doi:10.1084/jem. 172.6.1589

21. Moretta A, Tambussi G, Bottino C, Tripodi G, Merli A, Ciccone E, et al. A novel surface antigen expressed by a subset of human CD3-CD16+ natural killer cells. Role in cell activation and regulation of cytolytic function. J Exp Med (1990) 171(3):695-714. doi:10.1084/jem.171.3.695

22. Moretta A, Vitale M, Bottino C, Orengo AM, Morelli L, Augugliaro R, et al. P58 molecules as putative receptors for major histocompatibility complex (MHC) class I molecules in human natural killer (NK) cells. Anti-p58 antibodies reconstitute lysis of MHC class I-protected cells in NK clones displaying different specificities. J Exp Med (1993) 178(2):597-604. doi:10.1084/jem.178. 2.597

23. Yokoyama WM, Seaman WE. The Ly-49 and NKR-P1 gene families encoding lectin-like receptors on natural killer cells: the NK gene complex. Annu Rev Immunol (1993) 11:613-35. doi:10.1146/annurev.immunol.11.1.613

24. Wagtmann N, Biassoni R, Cantoni C, Verdiani S, Malnati MS, Vitale M, et al. Molecular clones of the p58 NK cell receptor reveal immunoglobulin-related molecules with diversity in both the extra- and intracellular domains. Immunity (1995) 2(5):439-49. doi:10.1016/1074-7613(95)90025-X

25. Pende D, Biassoni R, Cantoni C, Verdiani S, Falco M, di Donato C, et al. The natural killer cell receptor specific for HLA-A allotypes: a novel member of the p58/p70 family of inhibitory receptors that is characterized by three immunoglobulin-like domains and is expressed as a $140-\mathrm{kD}$ disulphide-linked dimer. J Exp Med (1996) 184(2):505-18. doi:10.1084/jem.184.2.505

26. Colonna M, Samaridis J. Cloning of immunoglobulin-superfamily members associated with HLA-C and HLA-B recognition by human natural killer cells. Science (1995) 268(5209):405-8. doi:10.1126/science.7716543

27. Vitale M, Sivori S, Pende D, Augugliaro R, Di Donato C, Amoroso A, et al. Physical and functional independency of p70 and p58 natural killer (NK) cell receptors for HLA class I: their role in the definition of different groups of alloreactive NK cell clones. Proc Natl Acad Sci U S A (1996) 93(4):1453-7. doi:10.1073/pnas.93.4.1453

28. Moretta A, Sivori S, Vitale M, Pende D, Morelli L, Augugliaro R, et al. Existence of both inhibitory ( $\mathrm{p} 58$ ) and activatory ( $\mathrm{p} 50)$ receptors for HLA-C 
molecules in human natural killer cells. J Exp Med (1995) 182(3):875-84. doi:10.1084/jem.182.3.875

29. Biassoni R, Cantoni C, Falco M, Verdiani S, Bottino C, Vitale M, et al. The human leukocyte antigen (HLA)-C-specific "activatory" or "inhibitory" natural killer cell receptors display highly homologous extracellular domains but differ in their transmembrane and intracytoplasmic portions. J Exp Med (1996) 183(2):645-50. doi:10.1084/jem.183.2.645

30. Parham P, Moffett A. Variable NK cell receptors and their MHC class I ligands in immunity, reproduction and human evolution. Nat Rev Immunol (2013) 13(2):133-44. doi:10.1038/nri3370

31. Vilches C, Parham P. KIR: diverse, rapidly evolving receptors of innate and adaptive immunity. Annu Rev Immunol (2002) 20:217-51. doi:10.1146/ annurev.immunol.20.092501.134942

32. Lopez-Botet M, Perez-Villar JJ, Carretero M, Rodriguez A, Melero I, Bellon $\mathrm{T}$, et al. Structure and function of the CD94 C-type lectin receptor complex involved in recognition of HLA class I molecules. Immunol Rev (1997) 155:165-74. doi:10.1111/j.1600-065X.1997.tb00949.x

33. Colonna M, Nakajima H, Cella M. Inhibitory and activating receptors involved in immune surveillance by human NK and myeloid cells. J Leukoc Biol (1999) 66(5):718-22.

34. Sivori S, Vitale M, Morelli L, Sanseverino L, Augugliaro R, Bottino C, et al. p46, a novel natural killer cell-specific surface molecule that mediates cell activation. J Exp Med (1997) 186(7):1129-36. doi:10.1084/jem.186.7.1129

35. Pessino A, Sivori S, Bottino C, Malaspina A, Morelli L, Moretta L, et al. Molecular cloning of NKp46: a novel member of the immunoglobulin superfamily involved in triggering of natural cytotoxicity. J Exp Med (1998) 188(5):953-60. doi:10.1084/jem.188.5.953

36. Vitale M, Bottino C, Sivori S, Sanseverino L, Castriconi R, Marcenaro E, et al. NKp44, a novel triggering surface molecule specifically expressed by activated natural killer cells, is involved in non-major histocompatibility complex-restricted tumor cell lysis. J Exp Med (1998) 187(12):2065-72. doi:10.1084/jem.187.12.2065

37. Cantoni C, Bottino C, Vitale M, Pessino A, Augugliaro R, Malaspina A, et al. NKp44, a triggering receptor involved in tumor cell lysis by activated human natural killer cells, is a novel member of the immunoglobulin superfamily. J Exp Med (1999) 189(5):787-96. doi:10.1084/jem.189.5.787

38. Pende D, Parolini S, Pessino A, Sivori S, Augugliaro R, Morelli L, et al. Identification and molecular characterization of $\mathrm{NKp} 30$, a novel triggering receptor involved in natural cytotoxicity mediated by human natural killer cells. J Exp Med (1999) 190(10):1505-16. doi:10.1084/jem.190.10.1505

39. Moretta A, Bottino C, Vitale M, Pende D, Cantoni C, Mingari MC, et al. Activating receptors and coreceptors involved in human natural killer cellmediated cytolysis. Annu Rev Immunol (2001) 19:197-223. doi:10.1146/ annurev.immunol.19.1.197

40. Bauer S, Groh V, Wu J, Steinle A, Phillips JH, Lanier LL, et al. Activation of NK cells and T cells by NKG2D, a receptor for stress-inducible MICA. Science (1999) 285(5428):727-9. doi:10.1126/science.285.5428.727

41. Shibuya A, Campbell D, Hannum C, Yssel H, Franz-Bacon K, McClanahan T, et al. DNAM-1, a novel adhesion molecule involved in the cytolytic function of T lymphocytes. Immunity (1996) 4(6):573-81. doi:10.1016/S1074-7613(00) 70060-4

42. Bottino C, Castriconi R, Pende D, Rivera P, Nanni M, Carnemolla B, et al. Identification of PVR (CD155) and Nectin-2 (CD112) as cell surface ligands for the human DNAM-1 (CD226) activating molecule. J Exp Med (2003) 198(4):557-67. doi:10.1084/jem.20030788

43. Cosman D, Mullberg J, Sutherland CL, Chin W, Armitage R, Fanslow W, et al. ULBPs, novel MHC class I-related molecules, bind to CMV glycoprotein UL16 and stimulate NK cytotoxicity through the NKG2D receptor. Immunity (2001) 14(2):123-33. doi:10.1016/S1074-7613(01)00095-4

44. Moretta L, Bottino C, Pende D, Vitale M, Mingari MC, Moretta A. Different checkpoints in human NK-cell activation. Trends Immunol (2004) 25(12):670-6. doi:10.1016/j.it.2004.09.008

45. Pogge von Strandmann E, Simhadri VR, von Tresckow B, Sasse S, Reiners KS, Hansen HP, et al. Human leukocyte antigen-B-associated transcript 3 is released from tumor cells and engages the NKp30 receptor on natural killer cells. Immunity (2007) 27(6):965-74. doi:10.1016/j.immuni.2007.10.010
46. Brandt CS, Baratin M, Yi EC, Kennedy J, Gao Z, Fox B, et al. The B7 family member B7-H6 is a tumor cell ligand for the activating natural killer cell receptor NKp30 in humans. J Exp Med (2009) 206(7):1495-503. doi:10.1084/jem.20090681

47. Baychelier F, Sennepin A, Ermonval M, Dorgham K, Debre P, Vieillard V. Identification of a cellular ligand for the natural cytotoxicity receptor $\mathrm{NKp} 44$. Blood (2013) 122(17):2935-42. doi:10.1182/blood-2013-03-489054

48. Castriconi R, Daga A, Dondero A, Zona G, Poliani PL, Melotti A, et al. NK cells recognize and kill human glioblastoma cells with stem cell-like properties. J Immunol (2009) 182(6):3530-9. doi:10.4049/jimmunol.0802845

49. Pietra G, Manzini C, Vitale M, Balsamo M, Ognio E, Boitano M, et al. Natural killer cells kill human melanoma cells with characteristics of cancer stem cells. Int Immunol (2009) 21(7):793-801. doi:10.1093/intimm/dxp047

50. Imai K, Matsuyama S, Miyake S, Suga K, Nakachi K. Natural cytotoxic activity of peripheral-blood lymphocytes and cancer incidence: an 11-year follow-up study of a general population. Lancet (2000) 356(9244):1795-9. doi:10.1016/S0140-6736(00)03231-1

51. Coca S, Perez-Piqueras J, Martinez D, Colmenarejo A, Saez MA, Vallejo C, et al. The prognostic significance of intratumoral natural killer cells in patients with colorectal carcinoma. Cancer (1997) 79(12):2320-8. doi:10.1002/(SICI)10970142(19970615)79:12<2320::AID-CNCR5>3.0.CO;2-P

52. Ishigami S, Natsugoe S, Tokuda K, Nakajo A, Che X, Iwashige H, et al. Prognostic value of intratumoral natural killer cells in gastric carcinoma. Cancer (2000) 88(3):577-83. doi:10.1002/(SICI) 1097-0142(20000201)88:3<577: :AID-CNCR13>3.0.CO;2-V

53. Villegas FR, Coca S, Villarrubia VG, Jimenez R, Chillon MJ, Jareno J, et al. Prognostic significance of tumor infiltrating natural killer cells subset CD57 in patients with squamous cell lung cancer. Lung Cancer (2002) 35(1):23-8. doi:10.1016/S0169-5002(01)00292-6

54. Sutlu T, Alici E. Natural killer cell-based immunotherapy in cancer: current insights and future prospects. J Intern Med (2009) 266(2):154-81. doi:10.1111/j.1365-2796.2009.02121.x

55. Halama N, Braun M, Kahlert C, Spille A, Quack C, Rahbari N, et al. Natural killer cells are scarce in colorectal carcinoma tissue despite high levels of chemokines and cytokines. Clin Cancer Res (2011) 17(4):678-89. doi:10.1158/1078-0432.CCR-10-2173

56. Sconocchia G, Spagnoli GC, Del Principe D, Ferrone S, Anselmi M, Wongsena W, et al. Defective infiltration of natural killer cells in MICA/B-positive renal cell carcinoma involves beta(2)-integrin-mediated interaction. Neoplasia (2009) 11(7):662-71.

57. Platonova S, Cherfils-Vicini J, Damotte D, Crozet L, Vieillard V, Validire $\mathrm{P}$, et al. Profound coordinated alterations of intratumoral NK cell phenotype and function in lung carcinoma. Cancer Res (2011) 71(16):5412-22. doi:10.1158/0008-5472.CAN-10-4179

58. Delahaye NF, Rusakiewicz S, Martins I, Menard C, Roux S, Lyonnet L, et al. Alternatively spliced NKp30 isoforms affect the prognosis of gastrointestinal stromal tumors. Nat Med (2011) 17(6):700-7. doi:10.1038/nm.2366

59. Remark R, Alifano M, Cremer I, Lupo A, Dieu-Nosjean MC, Riquet M, et al. Characteristics and clinical impacts of the immune environments in colorectal and renal cell carcinoma lung metastases: influence of tumor origin. Clin Cancer Res (2013) 19(15):4079-91. doi:10.1158/1078-0432.CCR-12-3847

60. Sconocchia G, Arriga R, Tornillo L, Terracciano L, Ferrone S, Spagnoli GC. Melanoma cells inhibit NK cell functions. Cancer Res (2012) 72(20):5428-9. doi:10.1158/0008-5472.CAN-12-1181 author reply 30,

61. Balsamo M, Vermi W, Parodi M, Pietra G, Manzini C, Queirolo P, et al. Melanoma cells become resistant to NK-cell-mediated killing when exposed to NK-cell numbers compatible with NK-cell infiltration in the tumor. Eur J Immunol (2012) 42(7):1833-42. doi:10.1002/eji.201142179

62. Carrega P, Morandi B, Costa R, Frumento G, Forte G, Altavilla G, et al. Natural killer cells infiltrating human nonsmall-cell lung cancer are enriched in CD56 bright $\mathrm{CD} 16(-)$ cells and display an impaired capability to kill tumor cells. Cancer (2008) 112(4):863-75. doi:10.1002/cncr.23239

63. Le Maux Chansac B, Moretta A, Vergnon I, Opolon P, Lecluse Y, Grunenwald $\mathrm{D}$, et al. NK cells infiltrating a MHC class I-deficient lung adenocarcinoma display impaired cytotoxic activity toward autologous tumor cells associated with altered NK cell-triggering receptors. J Immunol (2005) 175(9):5790-8. 
64. Mamessier E, Sylvain A, Thibult ML, Houvenaeghel G, Jacquemier J, Castellano $\mathrm{R}$, et al. Human breast cancer cells enhance self tolerance by promoting evasion from NK cell antitumor immunity. J Clin Invest (2011) 121(9):3609-22. doi:10.1172/JCI45816

65. Groh V, Wu J, Yee C, Spies T. Tumour-derived soluble MIC ligands impair expression of NKG2D and T-cell activation. Nature (2002) 419(6908):734-8. doi: $10.1038 /$ nature 01112

66. Roda-Navarro P, Vales-Gomez M, Chisholm SE, Reyburn HT. Transfer of NKG2D and MICB at the cytotoxic NK cell immune synapse correlates with a reduction in NK cell cytotoxic function. Proc Natl Acad Sci U S A (2006) 103(30):11258-63. doi:10.1073/pnas.0600721103

67. El-Gazzar A, Groh V, Spies T. Immunobiology and conflicting roles of the human NKG2D lymphocyte receptor and its ligands in cancer. J Immunol (2013) 191(4):1509-15. doi:10.4049/jimmunol.1301071

68. Gubbels JA, Felder M, Horibata S, Belisle JA, Kapur A, Holden H, et al. MUC16 provides immune protection by inhibiting synapse formation between NK and ovarian tumor cells. Mol Cancer (2010) 9:11. doi:10.1186/1476-4598-9-11

69. Balsamo M, Scordamaglia F, Pietra G, Manzini C, Cantoni C, Boitano M, et al. Melanoma-associated fibroblasts modulate NK cell phenotype and antitumor cytotoxicity. Proc Natl Acad Sci U S A (2009) 106(49):20847-52. doi:10.1073/pnas.0906481106

70. Castriconi R, Cantoni C, Della Chiesa M, Vitale M, Marcenaro E, Conte R, et al. Transforming growth factor beta 1 inhibits expression of NKp30 and NKG2D receptors: consequences for the NK-mediated killing of dendritic cells. Proc Natl Acad Sci U S A (2003) 100(7):4120-5. doi:10.1073/pnas.0730640100

71. Pietra G, Manzini C, Rivara S, Vitale M, Cantoni C, Petretto A, et al. Melanoma cells inhibit natural killer cell function by modulating the expression of activating receptors and cytolytic activity. Cancer Res (2012) 72(6):1407-15. doi:10.1158/0008-5472.CAN-11-2544

72. Krockenberger M, Dombrowski Y, Weidler C, Ossadnik M, Honig A, Hausler $\mathrm{S}$, et al. Macrophage migration inhibitory factor contributes to the immune escape of ovarian cancer by down-regulating NKG2D. J Immunol (2008) 180(11):7338-48.

73. Balsamo M, Manzini C, Pietra G, Raggi F, Blengio F, Mingari MC, et al. Hypoxia downregulates the expression of activating receptors involved in NK-cellmediated target cell killing without affecting ADCC. Eur J Immunol (2013) 43(10):2756-64. doi:10.1002/eji.201343448

74. Locatelli F, Pende D, Mingari MC, Bertaina A, Falco M, Moretta A, et al. Cellular and molecular basis of haploidentical hematopoietic stem cell transplantation in the successful treatment of high-risk leukemias: role of alloreactive NK cells. Front Immunol (2013) 4:15. doi:10.3389/fimmu.2013.00015

75. Copelan EA. Hematopoietic stem-cell transplantation. N Engl J Med (2006) 354(17):1813-26. doi:10.1056/NEJMra052638

76. Gluckman E. Cord blood transplantation. Biol Blood Marrow Transplant (2006) 12(8):808-12. doi:10.1016/j.bbmt.2006.05.011

77. Locatelli F, Pende D, Maccario R, Mingari MC, Moretta A, Moretta L. Haploidentical hematopoietic stem cell transplantation for the treatment of highrisk leukemias: how NK cells make the difference. Clin Immunol (2009) 133(2):171-8. doi:10.1016/j.clim.2009.04.009

78. Rocha V, Locatelli F. Searching for alternative hematopoietic stem cell donors for pediatric patients. Bone Marrow Transplant (2008) 41(2):207-14. doi:10. 1038/sj.bmt.1705963

79. Reisner Y, Kapoor N, Kirkpatrick D, Pollack MS, Cunningham-Rundles S, Dupont B, et al. Transplantation for severe combined immunodeficiency with HLA-A,B,D,DR incompatible parental marrow cells fractionated by soybean agglutinin and sheep red blood cells. Blood (1983) 61(2):341-8.

80. Aversa F, Tabilio A, Terenzi A, Velardi A, Falzetti F, Giannoni C, et al. Successful engraftment of T-cell-depleted haploidentical "three-loci" incompatible transplants in leukemia patients by addition of recombinant human granulocyte colony-stimulating factor-mobilized peripheral blood progenitor cells to bone marrow inoculum. Blood (1994) 84(11):3948-55.

81. Aversa F, Tabilio A, Velardi A, Cunningham I, Terenzi A, Falzetti F, et al. Treatment of high-risk acute leukemia with T-cell-depleted stem cells from related donors with one fully mismatched HLA haplotype. N Engl J Med (1998) 339(17):1186-93. doi:10.1056/NEJM199810223391702

82. Ruggeri L, Capanni M, Urbani E, Perruccio K, Shlomchik WD, Tosti A, et al. Effectiveness of donor natural killer cell alloreactivity in mismatched hematopoietic transplants. Science (2002) 295(5562):2097-100. doi:10.1126/ science. 1068440

83. Comoli P, Basso S, Zecca M, Pagliara D, Baldanti F, Bernardo ME, et al. Preemptive therapy of EBV-related lymphoproliferative disease after pediatric haploidentical stem cell transplantation. Am J Transplant (2007) 7(6):1648-55. doi:10.1111/j.1600-6143.2007.01823.x

84. Feuchtinger T, Matthes-Martin S, Richard C, Lion T, Fuhrer M, Hamprecht K, et al. Safe adoptive transfer of virus-specific T-cell immunity for the treatment of systemic adenovirus infection after allogeneic stem cell transplantation. $\mathrm{Br}$ J Haematol (2006) 134(1):64-76. doi:10.1111/j.1365-2141.2006.06108.x

85. Perruccio K, Tosti A, Burchielli E, Topini F, Ruggeri L, Carotti A, et al. Transferring functional immune responses to pathogens after haploidentical hematopoietic transplantation. Blood (2005) 106(13):4397-406. doi:10.1182/ blood-2005-05-1775

86. Moretta A, Locatelli F, Moretta L. Human NK cells: from HLA class I-specific killer Ig-like receptors to the therapy of acute leukemias. Immunol Rev (2008) 224:58-69. doi:10.1111/j.1600-065X.2008.00651.x

87. Pende D, Marcenaro S, Falco M, Martini S, Bernardo ME, Montagna D, et al. Anti-leukemia activity of alloreactive NK cells in KIR ligand-mismatched haploidentical HSCT for pediatric patients: evaluation of the functional role of activating KIR and redefinition of inhibitory KIR specificity. Blood (2009) 113(13):3119-29. doi:10.1182/blood-2008-06-164103

88. Klingebiel T, Cornish J, Labopin M, Locatelli F, Darbyshire P, Handgretinger $\mathrm{R}$, et al. Results and factors influencing outcome after fully haploidentical hematopoietic stem cell transplantation in children with very high-risk acute lymphoblastic leukemia: impact of center size: an analysis on behalf of the Acute Leukemia and Pediatric Disease Working Parties of the European Blood and Marrow Transplant group. Blood (2010) 115(17):3437-46. doi:10.1182/blood-2009-03-207001

89. Shilling HG, McQueen KL, Cheng NW, Shizuru JA, Negrin RS, Parham P. Reconstitution of NK cell receptor repertoire following HLA-matched hematopoietic cell transplantation. Blood (2003) 101(9):3730-40. doi:10.1182/ blood-2002-08-2568

90. Vitale C, Chiossone L, Cantoni C, Morreale G, Cottalasso F, Moretti S, et al. The corticosteroid-induced inhibitory effect on $\mathrm{NK}$ cell function reflects down-regulation and/or dysfunction of triggering receptors involved in natural cytotoxicity. Eur J Immunol (2004) 34(11):3028-38. doi:10.1002/eji. 200425418

91. Vitale C, Chiossone L, Morreale G, Lanino E, Cottalasso F, Moretti S, et al. Analysis of the activating receptors and cytolytic function of human natural killer cells undergoing in vivo differentiation after allogeneic bone marrow transplantation. Eur J Immunol (2004) 34(2):455-60. doi:10.1002/eji. 200324668

92. Pende D, Spaggiari GM, Marcenaro S, Martini S, Rivera P, Capobianco A, et al. Analysis of the receptor-ligand interactions in the natural killer-mediated lysis of freshly isolated myeloid or lymphoblastic leukemias: evidence for the involvement of the Poliovirus receptor (CD155) and Nectin-2 (CD112). Blood (2005) 105(5):2066-73. doi:10.1182/blood-2004-09-3548

93. Chewning JH, Gudme CN, Hsu KC, Selvakumar A, Dupont B. KIR2DS1positive NK cells mediate alloresponse against the C2 HLA-KIR ligand group in vitro. J Immunol (2007) 179(2):854-68.

94. Venstrom JM, Pittari G, Gooley TA, Chewning JH, Spellman S, Haagenson M, et al. HLA-C-dependent prevention of leukemia relapse by donor activating KIR2DS1. N Engl J Med (2012) 367(9):805-16. doi:10.1056/NEJMoa1200503

95. Cooley S, Weisdorf DJ, Guethlein LA, Klein JP, Wang T, Le CT, et al. Donor selection for natural killer cell receptor genes leads to superior survival after unrelated transplantation for acute myelogenous leukemia. Blood (2010) 116(14):2411-9. doi:10.1182/blood-2010-05-283051

96. Symons HJ, Leffell MS, Rossiter ND, Zahurak M, Jones RJ, Fuchs EJ. Improved survival with inhibitory killer immunoglobulin receptor (KIR) gene mismatches and KIR haplotype B donors after nonmyeloablative, HLAhaploidentical bone marrow transplantation. Biol Blood Marrow Transplant (2010) 16(4):533-42. doi:10.1016/j.bbmt.2009.11.022

97. Stern M, Ruggeri L, Mancusi A, Bernardo ME, de Angelis C, Bucher C, et al. Survival after $\mathrm{T}$ cell-depleted haploidentical stem cell transplantation is improved using the mother as donor. Blood (2008) 112(7):2990-5. doi:10.1182/blood-2008-01-135285 
98. Handgretinger R. New approaches to graft engineering for haploidentical bone marrow transplantation. Semin Oncol (2012) 39(6):664-73. doi:10.1053/ j.seminoncol.2012.09.007

99. Norell H, Moretta A, Silva-Santos B, Moretta L. At the bench: preclinical rationale for exploiting $\mathrm{NK}$ cells and gammadelta $\mathrm{T}$ lymphocytes for the treatment of high-risk leukemias. J Leukoc Biol (2013) 94(6):1123-39. doi:10.1189/jlb.0613312

100. Romagne F, Andre P, Spee P, Zahn S, Anfossi N, Gauthier L, et al. Preclinical characterization of 1-7F9, a novel human anti-KIR receptor therapeutic antibody that augments natural killer-mediated killing of tumor cells. Blood (2009) 114(13):2667-77. doi:10.1182/blood-2009-02-206532

Conflict of Interest Statement: Alessandro Moretta is a founder and shareholder of Innate-Pharma (Marseille, France). The remaining authors declare no conflicts of interest.
Received: 09 January 2014; paper pending published: 15 January 2014; accepted: 19 February 2014; published online: 07 March 2014.

Citation: Moretta L, Pietra G, Montaldo E, Vacca P, Pende D, Falco M, Del Zotto G, Locatelli F, Moretta A and Mingari MC (2014) Human NK cells: from surface receptors to the therapy of leukemias and solid tumors. Front. Immunol. 5:87. doi: 10.3389/fimmu.2014.00087

This article was submitted to NK Cell Biology, a section of the journal Frontiers in Immunology.

Copyright (C) 2014 Moretta, Pietra, Montaldo, Vacca, Pende, Falco, Del Zotto, Locatelli, Moretta and Mingari. This is an open-access article distributed under the terms of the Creative Commons Attribution License (CC BY). The use, distribution or reproduction in other forums is permitted, provided the original author(s) or licensor are credited and that the original publication in this journal is cited, in accordance with accepted academic practice. No use, distribution or reproduction is permitted which does not comply with these terms. 